\title{
The Space Aesthetics of In-Yer-Face Theatre in Phyllis Nagy's The Strip
}

\section{Amany El-Sawy}

Associate Professor, Faculty of Education, Alexandria University, Egypt.

\begin{abstract}
British theatre of the 1990s has witnessed the rise of a new angry young generation whose works have been labeled provocative, speculative, confrontational, sensational, shocking, taboo-breaking, brutal, bleak, gloomy and dark. These writers have a contemporary voice and pursue the aesthetics of 'In-yer-face' experiential theatre which launches rebellion against the classic well-made play, and against more recent literary traditions. Of those writers, contributing to (a)political drama in the 1990s, Phyllis Nagy emerged as one of the most influential figures, providing an experiential theatre with deeply shocking images. This paper is an attempt to explore the in-yer-face aesthetics in Nagy's The Strip by examining her manipulation of space and non-linear plot structures. Nagy creates isolated characters within oppressive worlds, and in the face of this seemingly undefeatable oppression, her characters share a bond that cannot be contained by traditional notions of space and time. Nagy bent the rules of physical space to give the audience a new and alienated perspective on traditional character relationships. In doing this, she makes it very difficult for an audience member to understand why the things on stage are happening. The Strip instead leaves audience members with a few clear impressions about life and society. Thus, this paper is an attempt to explore Phyllis Nagy's The Strip, and prove that she creates oppressive worlds onstage through unfamiliar, non-linear plot structures and that she connects the isolated characters through the distortion of onstage fictional space.
\end{abstract}

Keywords: Fictional space, In-yer-face theatre, Phyllis Nagy, Presentational space, The Strip, 
The in-yer-face movement came and went within a decade, but left its mark. Something about the aesthetic made theatre seem an essential way for Britons of the period to contemplate and reflect upon their society. It was a very youthful movement. It had its origins in Seneca, Artaud, the "angry young men" of the 1950s and 60s, and according to Ken Urban, it was closely tied into to the "Cool Britannia" movement (355). Nevertheless, a handful of Americans, Naomi Wallace, Phyllis Nagy, Timberlake Wertenbaker, Tracy Letts, and Rebecca Gilman, were not only writing in-yer-face plays and getting them produced in London, they were integral to developing and defining the aesthetic. Nevertheless, the works of Phyllis Nagy were clear standouts; not only were they the most successful, critically and financially, they were also the most provocative (357). Additionally, on Nagy's plays, Alistair Macaulay says "Each play I see by Phyllis Nagy confirms me in the belief that she is the finest playwright to have emerged in the 1990s" (267).

Nagy was simply one of the most prominent female in-yer-face playwrights. She distorted onstage space and time. The rules of physics known to the audience were suspended within the presentational space onstage. Nagy brought dead people onstage, sometimes as ghosts and sometimes as the person's former self. She had props that could travel thousands of miles with the flick of a wrist, and her characters could communicate across thousands of miles without the aid of technology. Indeed, Nagy is one of the prominent American in-yer-face playwrights who manipulated time and space in her plays to make large points and strong character connections.

In The Strip (1995), Nagy creates isolated characters within oppressive worlds, and in the face of this seemingly undefeatable oppression, her characters share a bond that cannot be contained by traditional notions of space and time. Michael Billington comments on the title and highlights its multilayer meaning:

The title refers to that famous stretch of fantasy land in Las Vegas, with its pyramid-shaped hotels and exotic casinos, to which all Nagy's characters are ultimately bound. But it also refers to the idea - which binds the play together that by stripping away our protective social selves, we can achieve a sense of life's endless possibilities. (1995)

The difficulty characters experience in locating themselves in time and space challenges the concept of difference and "otherness". Nagy is concerned with how people live with difference rather than deny it.

The Strip can be well understood through a spatial analysis. Thus, the aim of this paper is to examine Nagy's use of space, with an emphasis on fictional space in her in-yer-face play The Strip. Through the examination of space, this paper tries to illustrate how Nagy consistently breaks the rules of physics in her onstage fictional places to display that humans share an inexplicable but unbreakable bond. Moreover, it will prove that Nagy's segmentation of scenes creates a world of isolation from which there is no escape. Nonetheless, before untangling the mess of the mysterious world of The Strip, I will briefly focus on 'In-yer-face' theatre and how it launches a war against the well-established life of drama.

Aleks Sierz defined the in-yer-face theatre movement, and in his book In-Yer-Face Theatre: British Drama Today, he highlighted its main characteristics. According to Sierz,

[T]he language is usually filthy, characters talk about unmentionable subjects, take their clothes off, have sex, humiliate each another [sic], experience unpleasant emotions, become suddenly violent. At its best, this kind of theatre is so powerful, so visceral, that it forces audiences to react: either they feel like 
fleeing the building or they are suddenly convinced that it is the best thing they have ever seen, and want all their friends to see it too. It is the kind of theatre that inspires us to use superlatives, whether in praise or condemnation. (5)

Sierz is careful to point out that the vicious nature of these plays has a purpose, and the in yerface tactics are used to provoke the audience into paying particular attention to what the playwright has to say.

Although, Sierz's 2001 book is the most comprehensive study of the in-yer-face movement, his 2002 article, "Still In-Yer-Face? Towards a Critique and Summation," is more concise. He sees the "bigger picture" or "wider significance" of in-yer-face theatre as six fold. These include characteristics of social, cultural, and political impact and influence. One, inyer-face theater saved British theatre; "if it had not been for the small avant-garde of young writers in the 'nineties, I can imagine that new writing in Britain would be in a state of terminal decline" (20). Two, "In-yer-face theatre is the drama of new laddism." Some, including Sierz, saw in-yer-face theatre as a movement for and by men to celebrate masculinity and push back against the feminist movement. Three, "In-yer-face theatre is not a movement ... it's an aesthetic style." Four, In-yer-face theatre is a response to "changes in the wider world of politics and society (the end of the Cold War, a decline in left-wing militancy, the petering out of doctrinaire feminism)." Five, "In-yer-face theatre sets its face against postmodernism. Rather, it is modernist and avant-garde. It prefers old-fashioned ideas about political commitment and cultural provocation to new and trendy notions of irony, self-reflexivity, and cynicism" (2122). Finally, "In-yer-face is political theatre" (22), and Sierz draws the distinction between inyer-face plays and the "state-of-the-nation" plays by saying that in-yer-face theatre "explore[s] personal pain rather than public politics" (22).

In addition to the "bigger picture" Sierz lays out, he has one more illuminating list in his essay. He lists the "certain clear characteristics" of in-yer-face theatre (19). After listing the two most common characteristics of the in-yer-face aesthetic - its explicit depictions of sex and violence and its tendency to break taboos-Sierz claims the experiential nature of in-yerface is the most important:

In-yer-face theatre is experiential theatre, and it works because it exploits two of the special characteristics of the medium: first, because it's a live experience, anything can happen. The paradox is that while the audience is watching in perfect safety, it feels as if it is in danger. Second, theatre in Britain is technically uncensored, so everything is allowed. (19)

Sierz points out the "maturity of craft" the new writers possessed:

This can be summed up by the phrase 'the avoidance of closure'. Thus, in rebellion against the classic well-made play, and against more recent literary traditions, most 'nineties writers preferred to write work which doesn't finish with a climax in the 'right' place, doesn't have a clear message, and doesn't obey the dictates of naturalism. (19-20)

Nagy's work is defined by this last point more than any other. Her plays are experimentalespecially in structure - and they rarely resolve with a clear denouement. Rebecca Pritchard, a playwright herself, has commented on Nagy's The Strip. Pritchard highlights that Nagy is "making connections between very intimate, personal perspectives and a wider political reality". She is "challenging an audience to deconstruct the values of her society as represented onstage, rather than merely asking them to empathize" (in Saunders 10). 
In-yer-face playwrights often experimented with form, but the movement had wider cultural significance too. According to Urban, in his essay "Towards a Theory of Cruel Britannia: Coolness, Cruelty, and the Nineties," the in-yer-face face movement was a part of the "Cool Britannia" cultural movement: "This latest 'golden age' of British drama arose during a unique moment in the cultural history of the country - the reign of 'cool Britannia', when Britishness became Britain's favoured fetish. In the mid-nineties, London became ground zero for a revitalization of British art and culture" (Urban 355). In-yer-face plays present an alternative view of Britishness, and London as a place. London is not cool but cruel. Urban proves that in-yer-face plays attempted to change what "London" means as a signifier in plays. This was done by setting plays in London, but also by staging them there. In a nutshell, in-yerface plays are political plays that generally deal with personal politics over global politics. Their form is as shocking as their content, and they opposed the Cool Britannia movement by re-signifying London as a fictional onstage place. Also, by staging the plays in London, they redefined British culture and Britishness.

Sierz is the only scholar to examine Nagy as an in-yer-face playwright. When mentioning Nagy's role in establishing the in-yer-face movement, Sierz says she "did much to popularize the new aesthetic" (xiii). In an interview with Nagy, Sierz says:

As she says, 'We do need to ponder over the meaning of good plays beyond the moment in which we watch them. This is the essence of resonance.' Whether shocking, irritating or unsettling, Nagy's theatre subverts audience expectations. 'Provocation, because it stimulates thought, offers us a way forward.' In her work, meaning percolates slowly to the surface, seeping into consciousness long after the curtain has come down. A unique voice in nineties theatre, Nagy doesn't provide a comfortable theatrical experience, but you do feel that she embraces life wholly, in its warmth as well as its terrors" (53).

If Nagy's purpose of using unfamiliar form is to make the audience uncomfortable in order to provoke thought, then the key ingredient to unfamiliar form is unpredictability. Moreover, Sierz focuses on the provocative violence and overt homosexual activity onstage that are meant to shock her audience in Butterfly Kiss. Sierz avers: "What is shocking about Nagy's play is not the lesbian kiss, nor the final gunshot, but the picture-which we glimpse through the fractures of a highly elliptical style - of neediness and cowardice. The play's emotional core is about needing to be taken care of and to take care of others" (52). Besides promoting Nagy's skills at creating meaningful and compelling characters and story, Sierz is trying to prove his wider thesis about the shock tactics used in inyer- face theatre: they have a purpose outside of shocking for shock's sake. However, Nagy's "highly elliptical style" creates her plays, especially The Strip "emotional core," and this paper focuses on Nagy's use of such aesthetics to create meaning. The Strip has unfamiliar form; the characters' journeys dictate the structure, and Nagy distorts space and time to connect her characters in a desolate world.

The study of space is essential to understanding theatre (Chaudhuri xi). Gay McAuley's 2002 book, Space in Performance: Making Meaning in the Theatre, aims to prove that an understanding of space in theatre is essential to understanding theatre as an art form: "[T]he structures of spatial use, and the articulation of fictional place and dramatic event are fundamental to the thematic concerns of playwright and production. If we can understand the spatial system, we can unravel the philosophical and ideological content of play and production" (McAuley 33). McAuley claims that playwrights, equipped with a more complete understanding of how space works in theatre, are now consciously manipulating space to create meaning. Nevertheless, McAuley would argue against Bert O. States who maintains that the dramatist "assigns his play to a scene, designated by language or by objects in space, without 
troubling (my emphasis) to think how radically he has shifted the ground and conditions of our perception of the world. In a stroke he has altered our customary orientation to time and space" (States 48). States is correct about the impact of that shift, but he is mistaken that playwrights, especially those who are writing in the twenty first century, are not aware of the impact their creation of fictional space has on the spectator. An examination of Nagy's use of space would prove she knew exactly how much it disturbs and alienates her audience from their perception of the world.

In stating his purpose for the book, McAuley names all of the basic ways space functions in theatre and their importance to understanding theatre:

Starting from the perception of the vital importance of space in any understanding of the communication that occurs in theatre, the aim of the book is to explore the many ways in which space functions: the physical places of performance as they exist in the wider social space of the community, the space of interaction between performers and spectators, the energized space of the stage when it is occupied and rendered meaningful by the presence of performers, the organization of stage and offstage, the fictional places that are represented or evoked within or in relation to all these physical areas, and, interacting with all of them, the space of verbal reference. (McAuley 7)

Nevertheless, from McAuley's description of the field, one can see how broad it is. It includes the actual theatre buildings and the fictional locations created by the playwright. This paper focuses on what McAuley calls the "energized space of the stage." I will examine two ways that Nagy arranges "fictional places" (those occupied or created by the actors' presence or verbal reference). First, fictional places can be arranged in relation to each other in space. What fictional place is just offstage? Where are the actors exiting to? As for fictional places onstage, what is the spatial relationship - fictional and presentational-between numerous fictional places onstage simultaneously? Second, fictional places can be arranged in time. How does the nonlinear structure, which is an arrangement of fictional places out of chronology, affect the meaning of the play? These two arrangements of fictional place - space and time - are what distinguishes Nagy's play.

Most of the spatial terms are self-explanatory, but because of overlapping definitionsi.e. theatre space, stage space, performance space, presentational space-I will define some ambiguous terms. The "physical / fictional relationship" category of spatial function can be divided into three categories: stage space, presentational space, and fictional space (McAuley 25). Stage space is the physical playing area defined by the architecture of the building. Presentational space includes the scenery designed for the show, but since some shows have little or no scenery, an actor's presence is enough to define the presentational space. The notion must be seen to include the actual physical occupation of the stage space by the actors as well as the set (if any), its furniture and props, the spatial demarcation established by the lighting, the number, nature and position of the exits, and the way the offstage areas are signaled physically (29). Presentational space could also be thought of as "perceived space" (Scolnicov 14). This concept of perceived and conceived space, posited by Hanna Scolnicov, is almost consistent with McAuley's presentational space and fictional space. However, while offstage fictional space can always be considered "conceived" by the spectator, onstage fictional space is at times "perceived" and "conceived." McAuley necessarily separates presentational and fictional space, and since this paper discusses both, a further breakdown of fictional space is necessary. 
McAuley separates the category of fictional space into two types: onstage fictional space and offstage fictional space. Onstage fictional space can be physically represented by sets or props (even with minimal representation) or simply referred to and conceived by the audience. While McAuley's own approach includes actual performances, he does admit that there is a place for textual analysis in spatial studies. Nagy's presentational space comments on her fictional places; McAuley points out some differences in presentational structure: "In some plays, the presentational space gives us a single fictional place; in others multiple places are presented, either alternation or succeeding one another or simultaneously present in different parts of the stage space" (McAuley 30). Nagy often has simultaneous fictional places present in different parts of the stage space.

Typically, plays with one setting are more likely to call for set pieces that represent that setting. Plays with multiple settings are typically not staged realistically. They are restricted in the amount of representation they can have on stage because the stage needs to represent so many different locations. The Strip ${ }^{1}$ has multiple scenes and locations, but has a dominant set piece that represents one fictional place. It has the most iconic of set pieces. On the stage, there is a "re-creation of Sphinx and pyramid which represents the exterior of the Luxor Hotel, Las Vegas, Nevada. It never leaves the stage" (2). The set itself is an example of Baudrillard's third order simulation, and the play examines the hyperreality of contemporary landscapes. Dino Felluga claims that, according to Baudrillard, "what has happened in postmodern culture is that our society has become so reliant on models and maps that we have lost all contact with the real world that preceded the map" ("Modules on Baudrillard" 5). That is, reality has begun to imitate the model which precedes and determines the real world. According to Baudrillard, "the territory no longer precedes the map, nor does it survive it. It is nevertheless the map that precedes the territory-precession of simulacra - that engenders the territory" ("The Precession of Simulacra" 1). When it comes to postmodern simulation and simulacra, "It is no longer a question of imitation, nor duplication, nor even parody. It is a question of substituting the signs of the real for the real" (2). Baudrillard proposes that postmodern culture is artificial and requires some sense of reality against which to recognize the artifice. Nevertheless, people have lost all ability to make sense of the distinction between nature and artifice.

In The Strip, Nagy criticizes the chaotic modern Western world where characters can travel everywhere and nowhere. The characters' locations are across England and America, whilst all of the action takes place in front of the sphinx and pyramid of the Luxor Hotel in Las Vegas. The implications of having these multiple scenes and locations dominate the play's presentational space and what effect they have on the many fictional places is one of Nagy's defining characteristics. In The Strip, the characters are isolated, yet they are connected when Nagy substitutes presentational space for fictional space. While Otto Mink, a Mephistophelean character who wields control over each of the other characters' lives, can almost manipulate space at will, several other characters bend the rules of distance. By recognizing the distance within the presentational space instead of the imagined distance between two onstage fictional places, Nagy is able to emphasize an individual's impact on others and society at large.

The Strip opens with six separate scenes happening simultaneously on stage. Nagy uses the multiple scenes to introduce the characters in the first moment of the play. Madonna's song "Rescue Me" is playing in the background, further establishing each scene as happening at the same time. The scene with Ava, Otto, and Calvin carries a little more weight than the other scenes because Ava is lip-synching to the song. As an aspiring female impersonator, "Ava tries to look like Madonna ... OTTO and CALVIN are reticent" (3). In another scene, the quarrelling gay lovers, Tom and Martin, exercise in their Earls Court apartment. In a nearby hotel, Lester (Ku Klux Klan member and aspiring US congressman) polishes his boots while he watches the 
gay couple in their apartment. His wife, Loretta, is bottle feeding their infant son, Baby Ray, who is wearing miniature white KKK robes. Suzy — a fortune telling lesbian - is in her "Earls Court flat watching telly, eating crisps and masturbating simultaneously" (3). Kate, a private investigator and journalist, is "at her desk in Arlington, Virginia. She wears Walkman headphones. She cleans a 9mm, automatic pistol" (3). Lastly, Tina, Ava's mother, in Las Vegas is playing a slot machine. Nagy establishes the tone of this play by connecting, among others, a baby racist, a masturbating lesbian, and an old lady with a gambling problem. The simultaneous scenes, and the unifying music, connect these characters within the narrative.

After establishing the convention of simultaneous scenes and introducing the characters in their disparate locations, "The music fades into the sudden sound of a progressive slot machine jackpot being hit. Bells and sirens. A river of coins dropping out of slots. The sound is overwhelming" (3). Nagy then bends space and uses this sound to unite her characters: "Everybody listens to the phantom jackpot hit" (3). By responding to the sound of the jackpot, the characters and their narrative journeys are united within the presentational space. The sound of the jackpot has the added connotation that the characters are connected by greed, sense of entitlement, and acquisitiveness. When the jackpot sound ends, Nagy then asks for an "abrupt shift in focus" to the scene where Ava Coo is auditioning in a Long Island Hotel. Otto Mink says, "Female impersonation is a rather curious career choice for a woman, Miss Coo" (3). This opening line "has achieved classic status" (Coveney xii) and is typical of Nagy's brand of humor. This abrupt shift in focus is a distinguishing feature of The Strip. However, more important is the complexity and abundance of space bending devices; the bending of fictional space within the presentational space is apparent. Hence, the analysis of the space bending conventions in The Strip reveals the meaning of the play and gives insight into production.

The original London production of The Strip confused many in the audience. The ambiguity of relationships in The Strip might be confusing, but by placing these disparate characters onstage together, Nagy unites them. The characters in The Strip connect suddenly and shockingly through the manipulation of space. The question, "What do these characters have to do with each other?" is easily answered in the last scene, but it is unclear how some of the characters appeared in Las Vegas. Tina talks to Ava several times, either over the phone or through a taped message. The Marquette family-Lester, Loretta, and Baby Ray are visiting London and staying in an Earls Court hotel. They are in hiding because Lester is wanted for bombing a roadside diner full of black Baptist ministers. Otto Mink arranged this mass-murder, and he is backing Lester for an election bid to the US House of Representatives. In a nearby apartment, Martin is unkind to his lover Tom. Their friend Suzy-newly gifted at telling the future - is no help to either. Lester and Martin meet in a bar, and Lester becomes Martin's "hostage." Loretta and Baby Ray meet Tom in Greene and Greene pawn shop, where he works and Otto Mink / Murphy Greene is his boss. Loretta is there trying to sell her wedding ring. She and Baby Ray are running away. With Loretta and Baby Ray with Tom, and Lester with Martin, no one is at the hotel when Mink comes looking for Loretta. He has plans to marry her. This out-of-the-blue revelation ends the first act with Mink in a rage. Mink's resulting ragefilled scream initiates the most remarkable space bending in the play. When Mink finds Loretta, Baby Ray, and Tom, he takes them with him to Las Vegas. When Mink finds Lester and Martin, he puts Lester to work in the pawn shop as Tom's replacement and starts to groom Martin as the US House of Representative candidate.

Kate Buck and Suzy Bradfield travel separately to Las Vegas and do not meet until the end of the play, but they share a bond, which is examined below. Kate travels with Ava and Calvin, and Suzy travels with Tom, Loretta, and Baby Ray. At Mink's instruction, Kate is searching for Lester Marquette, the roadside diner murderer. Mink seems to be sending Kate 
on a journey similar to Ava's. He knows where and who the killer is, just as he knows where Tumbleweed Junction is. Kate has also answered what she thinks is a personal advertisement in a British magazine. Suzy receives these letters even though the only advertisement she has out is for her fortune telling business. Suzy spends most of the play avoiding Kate, until Mink delivers a letter to Suzy from Kate. The two meet just before the solar eclipse that Suzy claims is causing all of the coincidences.

The eclipse is something that looms over the play much as the onstage Sphinx and pyramid do. It is fitting that when the eclipse happens, there is a blackout and all of the characters re-enter in front of the Sphinx. Mink emerges from the Sphinx. He gives a carnival barker-type speech offering to sell the characters all manner of material goods. Baby Ray ends the play with an "oddly unsettling cry" (77). In short, after trying to meet, find, or run from something or someone, each character magically appears in Las Vegas. The man who has been controlling their actions emerges from the Sphinx and tries to sell them material goods. They all turn to look at the crying baby, just as they looked to the sound of the jackpot.

Many plays have two or three separate scenes happening simultaneously on stage. Often this is used to create some parallel between the disparate events happening onstage. The characters, in The Strip, sometimes feel and interact within the presentational space instead of the imagined distance between fictional onstage places. When characters or objects from different scenes interact across the fictional miles, the split focus is narrowed into one place and time. Two places becoming one alienate the audience from what they know about the restrictions of space. Therefore, this allows the audience to reevaluate the power and influence of the controlling character Otto Mink. It forces the audience to look afresh at the powerful mother daughter bond between Tina and Ava Coo and the promising bond between Kate and Suzy.

During the opening sequence, with all characters on stage at once, it would seem that Lester in his hotel room watching Tom and Martin in their apartment is a manipulation of space, but we find out later that the homophobic Lester somehow watches the gay couple through a circulation vent, which is impossible in reality. Nagy ignores these inconsistencies, instead using the stage space to define her sightlines. It is easy for the audience to believe this convention because the rooms and characters are visible from one another on stage, regardless of their imagined fictional distance. This early example of bending space hints at things to come. It establishes the convention and the bond between Lester and the homosexuals, especially Martin, who is the one doing the push-ups. Moreover, Earls Court near London and Arlington, Virginia are separated by the Atlantic Ocean. On stage however, a bouquet of flowers can be thrown from the onstage fictional Earls Court to the onstage fictional Arlington in an almost accidental way. In reality, this is impossible. On stage, it is not only possible, but this manipulation and alienation of space can be used to highlight the influence of an individual on others and society. The incident with the bouquet of flowers is just one of the space bending devices Nagy uses in The Strip, and an examination of Nagy's manipulation of space discloses how she alienates her audience's preconceived notions of relationships and individual control.

Nagy's manipulation of space tracks throughout the play, but it is more beneficial to look at the effect the practice has on each of the relationships. Suzy and Kate do not meet until the very end of the play, but Nagy forges a bond between them from their first sharing of the stage. Kate, in Arlington, Virginia silently reads a letter while Suzy, in Earls Court writes the same letter. As Suzy writes the letter, she reads it aloud. Kate listens as she reads. The audience would recognize the two characters as being in different places and times even as they are on stage together reading and writing the same letter. Having them there together visually represents their relationship for the audience, defining the relationship with two bodies in 
space. Nagy connects them again when she has a Ouija board spell out K-A-T-E-B-U-C-K to Suzy, Tom, Loretta, and Baby Ray. The Ouija board also spells out "LIVERPOOL" and "GREENEMINK," which they suppose to mean, "Go to Liverpool and look for something named "Greenemink." At the beginning of Act Two, the Ouija board group, including Suzy, is in Liverpool outside "the old law courts" (48), and Mink appears with gifts. He brings flowers for Loretta and a letter for Suzy from Kate; there is no explanation how he found them or knew about Kate and Suzy.

From this point forward, Suzy is obsessed with Kate, when before she was trying to avoid her. Nagy strengthens their relationship across the miles by bending space once more. As Suzy reads the letter Mink gave her aloud, Kate, Calvin, and Ava driving somewhere in Middle America. Just when Suzy finishes the letter, Kate honks the horn at another car on the road. Nagy's stage direction makes the connection across space: "KATE continues to blast the horn; SUZY reacts as if she, too, hears the horn wailing away" (54). From this point forward Suzy's attitude towards Kate changes, and she is determined to meet her. This bond, across thousands of miles, is enhanced by Nagy's distortion of space. The audience is alienated from their preconceived notions of how relationships form and how two individuals fall in love. The bond between Kate and Suzy defies logic, and their union seems inevitable. In addition to Mink's influence - possibly arranging delivery of the personal ad and definitely delivering the letter and sending Kate to the pawn shop in Earls Court where she finally meets Suzy-Nagy's bending of space makes the bond between Suzy and Kate seem like destiny. Mysteriously, when the two meet and are about to move towards each other, Nagy has the solar eclipse interrupt their inevitable meeting (75).

Just like Suzy and Kate, Ava and Tina connect across the miles throughout the play, and they only realize they are in the same hotel just before the eclipse. This makes more sense for Ava and Tina, who have obviously met before but are now estranged mother and daughter. Early in the play, Ava and Tina are speaking on the phone between Arlington and Las Vegas. Ava is looking for Tumbleweed Junction where Tina, her mother, works. Tina seems to hear Ava selectively, and Ava does not care what her mother is blathering about. Ava is drinking whiskey, and she desperately asks her mother:

AVA. You ever hear of some place called Tumbleweed Junction? Huh? Answer one of my friggin' questions, Ma, okay?

TINA. Oh honey, what's the point. Tell me. What is the point in answering questions when there are so many of them? That whiskey will rot your gut. My tummy's practically gone. I've drunk so much whiskey. (37)

It is clear from the last comment about the whiskey that Tina can see her daughter across the stage in Virginia, but Ava does not bother asking how her mother knew she was drinking whiskey. This is the end of a long conversation for Ava where her mother can inexplicably see her through the phone:

TINA. You look real pretty today, Ava, that blouse becomes you. But you shouldn't drink whiskey out of a bottle. It isn't lady like. (36)

To make matters worse for Ava, she finds out that the phone she used to call her mother has been disconnected for some time and does not work. Nagy does everything she can to confuse Ava and the spectator, leaving them only with the impression of an inexplicable but superhuman bond between mother and daughter. This is a perfect example of Nagy's style; clear impressions are achieved through inexplicable content. 
Later, Nagy defines Ava and Tina's relationship with an odd device. While Tina scrubs the bathroom floor at Tumbleweed Junction, she dictates a letter to Ava on the Dictaphone. At the same time, Ava is seen in a hotel room sorting through costumes with Calvin. When Tina gets frustrated, she wants to give up on her relationship with Ava: "And I don't know why I am recording this stuff honey, because you and me both know I'm never gonna send you the tape. The truth ain't never been a help to neither one of us but oh God I sure wish I knew what could be a help to us 'cause we need it bad" (61-2).

Then, "TINA drops the Dictaphone into the bucket of dirty water" (62), and Ava reacts:

AVA (clutches at her chest). Christ. Feels like my lungs are filling up with water. Shit. I think I'm drowning. (62)

Calvin moves to help Ava, but before he can do anything, Tina removes the Dictaphone and exits to play slots. Ava immediately recovers. Nagy uses this very illogical device to further define the mother-daughter connection. Ava's life and well-being are dependent on her mother's will to love and care. Without Tina's love, Ava dies. This device helps us understand the previous incidents of space bending and the end of the play.

Otto Mink (Murphy Greene) has influence over many of the characters' lives. Before establishing Mink as someone who can manipulate space at will, Nagy establishes him as a "traditional" controlling character. As the owner of the hotel where Ava is auditioning, Mink sends Ava in search of Tumbleweed Junction. "Find it and sing, Miss Coo" (6). Mink's few words have quite an impact on Ava's life. She leaves with Calvin in search of Tumbleweed Junction. Mink appears in the third scene as well. This time he is in the Tumbleweed Junction Casino, Las Vegas, and his name is Murphy Greene. He walks into the ladies room that Tina Coo is cleaning. Mink owns the casino where Ava's mother works, the same casino for which Ava is searching. He also owns the Dictaphone that Tina uses to send Ava taped messages. Mink takes the Dictaphone and docks Tina a day's pay because customers have been complaining "the loos aren't clean enough" (13). In just one scene, he has traveled thousands of miles and exerted his influence over a daughter and her mother. I mention this not because it is unusual or confusing for the audience, but because Nagy establishes Mink as an influential character in New York and Las Vegas. It is expected that subsequent chronological scenes will change place (i.e. Scene One is in New York, Scene Two is in London, Scene Three is in Las Vegas), but having Mink in New York and then in Las Vegas one scene later, visually represents him as someone who can be places fast.

In the fifth scene, Mink is in Arlington Virginia, again as Mr. Greene, checking on Kate's progress in finding evidence that Lester Marquette committed the roadside murder. In each of these three scenes, he is the boss. He is the owner of casinos and the coordinator of murder investigations. He controls lives on an intimate and cryptic level. Mink is mentioned in subsequent scenes as the owner of a pawn shop in Earls Court where Tom works and the backer of Lester's campaign for congress. In addition, Loretta tells Tom and Suzy how Mink orchestrated the roadside murder:

See, we [Lester, Loretta, and Mink] was sitting inside a Chevy Nova with this English Fella, you know, he's kinda like Lester's patron ... And then he goes, here, Lester, push the button. So Lester pushes the button and boom. Truck stop across the U.S. highway blows like a geyser. Boom. Just like that, we're fugitives, Lester and me. (49)

Mink is everywhere and known by everyone. By giving Mink such control over people and space, Nagy visually creates one individual with the power and identity usually reserved for 
several individuals. Once she establishes this ultimate control, Nagy distorts space to alienate the audience's preconceived conception of individual control in society by letting the audience see Mink as having power that defies sense or physics. Nagy's alienation of Mink's power seems to ask this question: "When one individual has absolute control over individuals in society, what effect does that influence have on society?" Nagy answers that question at the end of the play.

At the end of Act One, Mink is in Lester and Loretta Marquette's Earls Court hotel room with a bunch of flowers for Loretta. This is Mink's first appearance since he appeared in alternating scenes to open the play, establishing himself as the play's conductor. Nagy does not explain how Mink gained access to the room, but Mink chastises one of his unseen and anonymous minions over the phone for losing track of the Marquettes. He also reveals his plans for Loretta and the flowers:

OTTO: (into the phone) We had a date at the registry office for fuck's sake. Nono-you misunder-Marquette was unaware. Yes yes the divorce papers - look. The woman was to marry me today. Of course she didn't know. Why should she know? It was a bloody SURPRISE, man. (42)

It seems only Otto Mink has the influence to pull off something so audacious. That is not to say we are dealing with realism, which Nagy soon makes clear. As Mink fumes in the hotel room, other scenes start happening around him. In Virginia, Calvin visits JFK's grave and the eternal flame, while Kate and Ava are about to kiss. Tina is watching TV in Las Vegas. Loretta, Baby Ray, Tom, and Suzy are using a Ouija board, and elsewhere in Earls Court, Lester claims Martin kidnapped him, but Lester is obviously going through some sexual identity crisis, especially when Martin forcibly grabs Lester's testicles. All of this happens onstage simultaneously, until Mink "drops to his knees and lets out a quite unearthly and long cry of sorrow and deep pain. He flings the gorgeous bunch of flowers away" (43). Then the stage directions describe the events that happen simultaneously, each character obviously reacting to hearing Otto's scream.

The girls in Arlington cover their ears; "Ava faints, dead away" (43). Martin flings himself off Lester "as if he's been hit in the stomach" (43). Tina's television explodes. The Ouija board's pointer "flies off violently and with great speed, up up and away" (43). As these things happen "simultaneously," Nagy finishes the act with the most space bending and alienating stage directions:

OTTO's bunch of flowers lands at JFK's grave at Arlington National Cemetery. The eternal flame is suddenly extinguished. And without warning or prelude, the sound of a tremendous approaching storm, like a hurricane or a tornadowind, like a portent, overwhelms the space. AVA sits up suddenly, wide awake. The space darkens ominously, as if it's closing in on its inhabitants. Everybody looks to the sky as if it holds some kind of common answer. Blackout. End of Act One. (43)

Nagy defies the Atlantic's breadth, emphasizing Mink's control with a complicated bit of stage business; it must be difficult to accurately throw a bouquet of flowers even five feet across the stage. The extinguished flame clearly causes the storm. Again, Nagy uses a space bending incident to connect the characters. What does it all mean though? When a character with near omnipotent and omniscient powers extinguishes JFK's eternal flame in a jealous rage, what is the audience to think when a sudden storm approaches and characters separated by thousands of miles look to the sky in unison? The meaning of these related events is, to say the least, ambiguous. However, if we look at the stage business in broad terms, Nagy's message becomes 
clear. When Mink lets his emotions get out of control, the flowers in his hand fly across the miles and extinguish the eternal flame. Nagy asserts the fact that when people in power act out of emotion, which they are likely to do, a small part of society is gone forever. A spectator cannot help but contemplate the impact of individuals wielding too much power when the eternal flame is extinguished in such a peculiar and trivial manner.

At the beginning of Act Two, Mink's unexpected arrival at the law courts just adds to his mysteriousness and marks his relationship with Loretta and Suzy's relationship with Kate as inevitable and under Mink's control. Nagy continues to establish the bonds between characters. She does this by manipulating space and in ways that are more traditional, like having the characters in the same place. Nagy's emphasis on Mink's unnatural power, and the inevitable converging of characters with inexplicable bonds, is most clearly understood through an analysis of the last moments of the play when the solar eclipse arrives and Otto Mink emerges from the Sphinx.

The solar eclipse Suzy predicted is moments away. Ava, Calvin, and Kate arrive in Las Vegas, randomly stumbling upon Tumbleweed Junction. After speaking to Mink on the phone, Kate disappears in search of Lester. Ava and Tom enter Tumbleweed Junction, and soon after, Ava is seen lip-synching her routine. Tom, Loretta, Baby Ray, Mink, and Martin are on a plane fortuitously headed towards Las Vegas: "I can't believe the only flight we could get was a flight to Las Vegas" (74). Suzy and Lester are in Earls Court in Greene and Greene pawn shop. Suzy wears a sandwich board sign that says "Kate Buck" as she yells through a megaphone: "Something's coming don't know when don't know why something's coming don't know how don't know where watch your back watch your toasters your guitars your electric blankets something's coming" (74). This borrowing of lyrics from West Side Story does seem to hint at a resolution to the characters' journeys. Even though Suzy could not have found a less effective communication method than sandwich board and megaphone, Kate walks into the pawn shop, meeting Suzy for the first time. At Tumbleweed Junction, Ava's music cuts out, and she is left onstage "singing the song on her own" (73). Tina hears this familiar voice and starts to move towards her daughter. The group on the jumbo jet is about to land in Las Vegas:

TOM. Are we in Egypt? I see a pyramid.

LORETTA. Baby Ray, looky: the sun's getting bigger and darker and ain't it just something to witness? (75)

Nagy inaugurates that all character journeys are about to be resolved, but then the sun is eclipsed and there is a black out. When the lights come up, there is no plane, no pawn shop, and no Tumbleweed Junction. "Lights up suddenly on TINA and BABY RAY, alone in the landscape. Baby Ray is on the ground. Tina picks him up" (75). All except Mink enter in pairs, "unsure of where they are. The pairs should be: AVA and SUZY; TOM and LESTER; LORETTA and CALVIN; KATE and MARTIN. SUZY holds a toaster" (76). Each pair consists of two characters who have never met, on or offstage. Nagy creates a clean relationship slate; pairing the characters with the one they have the fewest connections. They have not forgotten though. They soon start to greet each other. Just like the audience, they do not know how they arrived there:

TOM. Suzy. We went someplace, didn't we?

SUZY. We went back. Or forwards. I'm not sure. (Beat: she holds out the toaster to TOM.) In any event, I brought a gift. (76) 
If the audience and the characters are overwhelmed and confused at this point, Nagy has them against the ropes and is about to knock them out. As characters reunite with their loved ones, something strange starts to happen:

And then, a sudden unearthly rumbling sound from the deepest bowels of the earth. The sphinx/pyramid splits open to reveal OTTO, like Samson, pushing its walls apart.

OTTO. What's your desire what's the situation I'll tell you the situation: I've got booze I've got car stereos I've got fax modems I've got what you want I've got what you want I've got what you WANT. (76-7)

Otto Mink begins to laugh. Baby Ray begins to cry. "Everyone turns to look at BABY RAY" (77), and Tina tries to console the foundling: "Oh little boy, you can't cry. Dontcha know you're in Vegas? You're gonna love it here. There's lots of action. And chance. SO much chance it gives you goose bumps. [...] We got possibilities, little fella, endless possibilities" (77). Then there is stillness, as they all listen to BABY RAY's oddly unsettling cry. Just as everyone looked to Mink when he screamed in Earls Court, Baby Ray's cry unifies the cast. Nagy hints at Baby Ray's powers earlier in the play. Loretta claims she can communicate with him without speaking, (33) and he is the one controlling the Ouija board pointer (41). Nagy finishes the play hinting that Baby Ray is the future. It is a bleak and oppressive future, and all heads turn to the crying baby.

In short, the final moment leaves the audience with more questions than answers. This is how Nagy creates an in-yer-face play that provokes thought through social commentary. Without onstage sex or violence, Nagy created a very disturbing in yer- face play. She bent the rules of physical space to give the audience a new and alienated perspective on traditional character relationships. In doing this, she makes it very difficult for an audience member to understand why the things on stage are happening. The Strip instead leaves audience members with a few clear impressions about life and society. Some might be disturbed by the level of control some individuals have over other's life; nonetheless, they will leave disturbed into contemplation.

To conclude, Nagy's manipulation of stage space in The Strip is not only intentional, but she uses it to great effect. Nagy makes her point more effectively and in-yer-face through her manipulation of stage space. She creates oppressive world onstage through unfamiliar plot structures and that she connects the isolated characters through the distortion of onstage fictional space. The Strip opens with six separate onstage fictional places represented simultaneously within the presentational space. The ever-present Sphinx and pyramid dominate the presentational space and comment, as usual, on the onstage fictional places within it. During the simultaneous scenes, Nagy distorts space, connecting the characters in separate scenes across the miles. Suzy and Kate can feel and hear each other across the miles, even though they have never met. Ava and her mother Tina share a bond that transcends space even though they cannot communicate on the phone. Ava can see her daughter and make her stop breathing by dropping a Dictaphone in a bucket.

The connections these two sets of characters make within the presentational space are seemingly out of their control. However, in The Strip, Otto Mink has the ability to control space. He can appear as if from nowhere, and his screams are heard around the world. By having this powerful character control minor events in the characters' lives - sending Kate and Ava on journeys, hiring Tom and Lester, giving Suzy a letter - and by having his actions larger social implications in the world - extinguishing the eternal flame, funding a congressional campaign - Nagy emphasizes the dangers of individuals wielding too much power. When 
Mink emerges from the pyramid at the end of the play, hawking wares, Nagy hints that powerful characters oppress the masses by promoting materialism and acquisitiveness. The sudden inclusion of this commentary against capitalistic oppression-when the play dealt with personal connection, homophobia, and racism - is almost as unpredictable as having Baby Ray closes the play with his wailing cry after he had not spoken a word the whole play.

Thus, by visually representing inexplicable but unbreakable bonds onstage, and having Baby Ray's wailing cries close the play, The Strip shows how human connection transcends all obstacles. By giving Mink the ability to exploit that innate connection, Nagy visually represents an individual with the power and identity usually reserved for several individuals. What Nagy does, and what makes her worthy of study and admiration, is her arrangement of onstage fictional spaces and times in an unfamiliar way, putting the burden on the spectator. "[If] what you want is a passive experience, then theatre is not the right medium" (Nagy in Sierz 50). Nagy's contribution to the art of theatre is creating distinct, effective, and powerful theatre that puts the burden of thought on the spectator who must decide whether the unbreakable human connection can survive in this most oppressive and pessimistic outlook on society.

\section{Notes}

1 Since Nagy's arrangement of onstage fictional spaces and times is in an unfamiliar way, she puts the burden on the spectator. Thus a thorough focus on the characters and the events will be highlighted in the paper to link the distorted space with the fragmented structure of the play.

\section{Works Cited}

Baudrillard, Jean. Simulacra and simulation. Ann Arbor : University of Michigan Press,1994.

Billington, Michael. 'Strip searchers'. Review of The Strip, by Phyllis Nagy. Royal Court, London. The Guardian, 3 March 1995. Reprint in Theatre Record XV (5) (26 February1I March), p. 266.

---. "East End Bullies at the Royal Court." Rev. of Herons by Simon Stephens. The Guardian. 24/5/2001.http://arts.guardian.co.uk/reviews/story/ 0703339,00.html 14/2/2020.

Chaudhuri, Una. Staging Place: The Geography of Modern Drama. Ann Arbor: University of Michigan Press, 1995.

Coveney, Michael. "Introduction." Phyllis Nagy. Plays: 1 London: Methuen, 1998. xi-xvi.

Felluga, Dino. "Modules on Baudrillard: On Simulation." Critical Theory: The Key Concepts: Routledge, 2015.

Logan, Brian. "Everyday Madness". 14/8/2006. The Guardian http://arts.guardian.co.uk/ edinburgh2006/story/0,,1844101,00.html 9/12/2019.

Macaulay, Alistair . "Nagy's strange task in The Strip". Review of The Strip, by Phyllis Nagy. Royal Court, London. The Financial Times, 2 March. Reprint in Theatre Record XV (5) (26 February- 11 March) 1995, p. 267.

McAuley, Gay. Space in Performance: Making Meaning in the Theatre. Ann Arbor: University of Michigan Press, 1999.

Nagy, Phyllis. The Strip. London: Nick Hern, 1995. 
Saunders, Graham. Love me or Kill Me: Sarah Kane and the theatre of extremes. Manchester: Manchester University Press, 2002.

Scolnicov, Hanna. Woman's Theatrical Space. Cambridge: Cambridge University Press, 1994.

Sierz, Aleks. In-Yer-Face Theatre: British Drama Today. London: Faber and Faber, 2001.

---. "Still In-Yer-Face? Towards a Critique and Summation". New Theatre Quarterly. Feb. 2002. Vol. 18, Issue 1. Search < http://journals.cambridge.org/> 12/12/19. 7-24.

States, Bert O. Great Reckonings in Little Rooms: On the Phenomenology of Theater. Berkeley: University of California Press, 1985.

Urban, Ken. "Towards a Theory of Cruel Britannia: Coolness, Cruelty, and the Nineties". New Theatre Quarterly. Vol. 20, Issue 4. October 2004. Search <Cambridge Journals Online> 354-372. 